\title{
Pengembangan Media Video Bimbingan Konseling untuk Mengurangi Perilaku Bullying
}

\author{
Agrianur Rahman \\ Bimbingan Konseling, Universitas Negeri Makassar, Indonesia \\ Email: agrianur_rahman@yahoo.co.id \\ Farida Aryani \\ Bimbingan Konseling, Universitas Negeri Makassar, Indonesia \\ Email: farayani77@yahoo.com \\ Abdullah Sinring \\ Bimbingan Konseling, Universitas Negeri Makassar, Indonesia \\ Email: abdullahsinring@unm.ac.id
}

(Diterima: 01-Januari-2018; direvisi: 09-Mei-2018; dipublikasikan: 30-Juni-2018)

\begin{abstract}
The research aims to (1) the description of development needs of Guidance and Counseling Video Media to Reduce Bullying Behavior, (2) the prototype of Guidance and Counseling Video Media to Reduce Bullying Behavior which is valid and acceptable, (3) the acceptance of Guidance and Counseling Video Media to Reduce Bullying Behavior in SMAN 5 Makassar. The research was development research or research and development which was based on research stages by Borg and Gall. The research employed collecting data technique through interview and scale. The results of research revealed that (1) the description of needs level of Guidance and Counseling Video Media to Reduce Bullying Behavior showed that the video media very important and needed, (2) the prototype of Guidance and Counseling Video Media developed was already valid and acceptable to Reduce Bullying Behavior, (3) the acceptance of Guidance and Counseling Media Video which was given to 10 students in small group test showed that there was change of bullying behavior level before and after viewing Guidance and Counseling Video Media. This meant that guidance and counseling media video could reduce bullying behavior.
\end{abstract}

Keywords: guidance and counseling; video media; bullying.

Abstrak: Penelitian bertujuan untuk (1) Mengetahui gambaran kebutuhan pengembangan media video bimbingan konseling untuk mengurangi perilaku bullying. (2) Mengetahui prototipe media video bimbingan konseling untuk mengurangi perilaku bullying yang valid dan acceptable. (3) Mengetahui keberterimaan media video bimbingan konseling untuk mengurangi perilaku bullying. Penelitian ini penelitian pengembangan yang berdasarkan tahapan penelitian oleh Borg and Gall. Penelitian menggunakan teknik pengumpulan data wawancara dan skala. Hasil penelitian menunjukkan bahwa (1) Gambaran tingkat kebutuhan media video bimbingan konseling untuk mengurangi perilaku bullying siswa di SMAN 5 Makassar menunjukkan bahwa media video sangat penting dan dibutuhkan (2) Prototipe media video bimbingan konseling yang dikembangkan telah valid dan acceptable untuk mengurangi perilaku bullying 3) Keberterimaan media video bimbingan konseling yang diberikan kepada 10 siswa dalam uji kelompok kecil menunjukkan adanya perubahan tingkat perilaku bullying sebelum dan setelah penayangan media video bimbingan konseling. Hal ini berarti media video bimbingan konseling dapat mengurangi perilaku bullying.

Kata kunci: media video; bimbingan konseling; bullying

Copyright (C) 2018 Universitas Negeri Makassar. This is an open access article under the CC BY-NC-ND license (http://creativecommons.org/licenses/by-nc-nd/4.0/). 


\section{PENDAHULUAN}

Data yang dilansir dari Komisi Perlindungan Anak Indonesia (KPAI) bahwa saat ini kasus bullying menduduki peringkat teratas pengaduan masyarakat. Dari 2011 hingga agustus 2014, KPAI mencatat 369 pengaduan terkait masalah tersebut. Jumlah itu sekitar $25 \%$ dari total pengaduan di bidang pendidikan sebanyak 1.480 kasus. Bullying yang disebut KPAI sebagai bentuk kekerasan di sekolah, mengalahkan tawuran pelajar, diskriminasi pendidikan, ataupun aduan pungutan liar (Komisi Perlindungan Anak Indonesia, 2014).

Pelaku memiliki kekuatan yang lebih tinggi sehingga mereka dapat mengatur orang lain yang lebih lemah. Namun tidak menutup kemungkinan bullying dapat dilakukan oleh teman sekelas baik perseorangan maupun kelompok. Berdasarkan penelitian bahwa jika peserta didik menghargai dirinya dengan baik maka ia dapat menghindari dirinya dari dampak tindakan bullying. Peserta didik perlu memahami bahwa pelaku bullying (bully) biasanya ingin melihat targetnya menjadi emosi. Jadi sangat baik jika tetap bersikap tenang dan jangan membuat bully senang karena bisa membuat korbannya marah.

Aksi bullying paling tidak melibatkan dua aktor utama yaitu pelaku dan korban. Akan tetapi, banyak situasi menunjukkan bahwa dalam aksi bullying muncul pula warga sekolah yang menyaksikan aksi tersebut yang biasa disebut bystander atau saksi mata, baik secara aktif maupun pasif (Costrie,2009). Terdapat empat jenis peranan bystander dalam aksi bullying yaitu(1) mendukung atau menyoraki, (2) terlibat sebagai pelaku, (3) menyaksikan dengan pasif, (4) melakukan intervensi (Salmivalli dkk., 1996). Bullying juga termasuk prilaku agresif yang mengganggu kenyamanan dan menyakiti orang lain (Kowalski, 2013) Serta Cyberbullying terjadi antara anak-anak; antara orang dewasa; juga di seluruh kelompok usia yang berbeda, (Developed for the Department for Children, 2007). Tentu prilaku ini terjadi disebabkan berbagai faktor yaitu Impulsif (memiliki emosi yang meledak-ledak, dan kurang dapat mengontrol diri (National Center for Injury Prevention and Control, 2011), faktor demografi, yatim piatu, kepemilihan ( (Wang, 2009), lingkungan dan keluarga
(Modecki, 2014) (Bakhtiar, 2015). Dampak cyberbullying dan bullying harus mendapat perhatian khsuus karena memberikan dampak yang buru kepada generasipelajar disekolah (Aryani \& Bakhtiar, 2018)

Berdasarkan penjelasan diatas, maka peneliti berinisiatif bahwa bullying harus dihentikan setidaknya mengurangi tindakan bullying disekolah karena diketahui bullying memiliki efek negatif terhadap kelangsungan hidup peserta didik, diantaranya di Indonesia ditemui kasus-kasus bullying yang menyebabkan korban terluka bahkan meninggal. Bullying menyebabkan stress pada peserta didik, kurangnya kepercayaan diri, kesepian dan gangguan kecemasan. Bullying mempengaruhi relasi sosial, anak yang merasa ditolak bisa menarik diri dari hubungan sosial yang berakibat mereka tidak memiliki kesempatan untuk mengembangkan keterampilan sosial yang dibutuhkan. Selain itu, berpengaruh negatif terhadap semangat dan pembelajaran dan prestasi peserta didik.

Guru BK merasa memerlukan alat bantu berupa media video untuk mengurangi perilaku bullying di sekolah yang kian marak terjadi. Penggunaan media bisa dikatakan jarang dimanfaatkan dalam kelas. Adapun upaya bimbingan dan konseling yang dilaksanakan oleh guru BK di sekolah untuk mengurangi perilaku bullying adalah melalui layanan informasi. Guru BK memberikan berbagai informasi mengenai bahaya bullying menggunakan buku ajar (LKS), yang bagi para peserta didik sangat membosankan. Materi dalam LKS tersebut hanya memberi sedikit penjabaran dan hanya berkutat tentang tenggang rasa dan sopan santun. Namun, hal tersebut dirasa belum efektif sebab yang diberikan hanyalah dalam bentuk layanan informasi yang sulit dipahami siswa. Layanan informasi di kelas tidak pernah memanfaatkan media apapun. Oleh karena itu, peneliti menggunakan media video ini agar peserta didik lebih tertarik untuk mengikuti pemberian layanan sehingga berkurangnya perilaku bullying.

Media dapat mewakili apa yang kurang mampu guru BK ucapkan melalui kata-kata atau kalimat tertentu. Bahkan keabstrakan bahan dapat dikonkretkan dengan kehadiran media. Media video ini merupakan salah satu media yang dapat memberikan dampak yang positif jika digunakan dengan baik karena penggunaan media video memiliki manfaat 
selain meningkatkan minat peserta didik dalam mengikuti kegiatan, dan peserta didik sendiri sebagian besar lebih cenderung menyukai hal yang berhubungan dengan visual. Media Video meningkatkan partisipasi dalam meningkatkan keterampilan sosial siswa, (Bakhtiar, 2015), Video dapat menjelaskan konten lebih nyata ( (Batubara \& Ariyani, 2016) sehingga video menjadi pendting dalam memberikan pesan layanan kepada siswa

Video ini berisi gambaran kepada peserta didik tentang dampak negatif bullying bagi pelaku dan korban. Video cocok diberikan kepada siswa karena mampu memperlihatkan objek dan peristiwa dengan tingkat akurasi dan realisme yang tinggi. Disamping itu, media video memiliki kemampuan untuk memperluas wawasan pengetahuan siswa dengan menampilkan informasi, pengetahuan baru dan pengalaman belajar yang sulit diperoleh secara langsung oleh siswa. Media ini juga mampu merangsang minat belajar melalui penyajian gambar dan informasi yang menarik (Pribadi, 2004:52).

Siswa belajar melalui media ajar yang disajikan secara audio visual sehingga lebih memberikan gambaran langsung yang lebih dalam dan menyentuh perasaan. Perasaan siswa akan tersentuh jika diposisikan sebagai pelaku maupun korban bullying. Video dapat memberikan kesempatan bagi siswa untuk belajar memahami apa itu perilaku bullying, bentuk-bentuk bullying, akibat bullying, dan contoh upaya kesadaran anti bullying.

Dengan kata lain, video mengandung pengetahuan dan nilai-nilai edukasi agar siswa sadar bahwa tindakan bullying harus diperangi atau dihentikan. Bagi siswa yang sudah terbiasa melakukan bullying, video ini membantu anak untuk menyadarkan bahwa tindak bullying yang telah dilakukan adalah tidak baik.

Video memiliki kelebihan merespon kembali perasaan, emosi dan masalah yang dihadapi klien melalui penayangan video. Video efektif membantu mengatasi masalah klien yang dihadapi melalui penayangan video yang sesuai dengan masalah klien (Mustafa, 2011).

\section{METODE}

Jenis penelitian merupakan penelitian dan pengembangan (research and development). Model pengembangan yang digunakan dalam penelitian ini mengacu pada model pengembangan yang dikemukakan oleh Borg and Gall (Mulyataningsih, 2014: 163-165).

Agar media pengembangan BK ini mengacu pada strategi di atas relevan dengan tujuan penelitian ini, maka peneliti merumuskan langkah-langkah pengembangan menjadi seperti berikut ini: (1) Riset awal dan pengumpulan informasi (Research and information collection); (2) Perencanaan pengembangan (Planning); (3) Penyusunan format model awal (Develop Preliminary Form of Product); (4) Pengembangan modul awal melalui validasi modul/ahli (Preliminary Field Testing); (5) Revisi model utama (Main Product Revision) / Revisi I; (6) Uji kelompok kecil; (7) Revisi II; (8) Deseminasi dan implementasi

$$
\text { Penelitian pengembangan ini }
$$

dilakukan pada peserta didik SMAN 5 Makassar, setelah terlebih dahulu mengadakan observasi dan wawancara untuk memperoleh data informasi. Sekolah tersebut dipilih karena berdasar dari hasil analisis kebutuhan guru $\mathrm{BK} /$ konselor dan pembagian skala kepada siswa didapatkan fakta bahwa disekolah tersebut terdapat beberapa peserta didik yang sering melakukan bullying.

Peneliti akan menggunakan teknik pemilihan sampel dengan cara purposive sampling atau sampel bertujuan. Purposive sampling dilakukan dengan cara mengambil subyek bukan didasarkan atas strata, random, atau daerah, tetapi didasarkan atas adanya tujuan tertentu. Dasar inilah peneliti memilih sampel sebanyak 10 siswa sebagai uji coba kelompok kecil, sebagai subyek uji coba kelompok dalam pengembangan media video yang dipilih menurut kondisi siswa yang mengalami dan melakukan bullying. Untuk mengumpulkan data yang diperlukan dalam pengembangan media video bimbingan konseling untuk mengurangi perilaku bullying digunakan dua macam instrumen pengambilan data yakni wawancara dan skala bullying.

Teknik analisis data yang digunakan untuk mengolah data yang diperoleh dalam pengembangan media video bimbingan konseling untuk mengurangi perilaku bullying ini adalah dengan menggunakan analisis kualitatif dan analisis kuantitatif.

Jawaban yang diperoleh melalui skala atau checklist dijumlahkan atau dikelompokkan sesuai dengan bentuk instrumen yang digunakan. Skala yang digunakan dalam penelitian ini daftar yang berisi pertanyaanpertanyaan yang harus dijawab oleh siswa 
selaku subjek tindakan. Angket yang digunakan dalam penelitian ini adalah angket dengan bentuk jawaban ya dan tidak, maka sebelum dilakukan analisa peneliti menjumlahkan seberapa banyak jawaban sesuai dan seberapa jawaban tidak sesuai kemudian peneliti mempresentasekan dengan menggunakan rumus skala guttman.

Jawaban dari responden dapat dibuat skor tertinggi "satu" dan skor terendah "nol", untuk alternative jawaban dalam skala. Penyusun menetapkan kategori untuk setiap pernyataan positif, yaitu $\mathrm{Ya}=1$ dan Tidak $=0$, sedangkan kategori untuk setiap pernyataan negative, yaitu $\mathrm{Ya}=0$ dan Tidak=1.

\section{HASIL DAN PEMBAHASAN}

1. Gambaran kebutuhan pengembangan Media Video Bimbingan Konseling Untuk Mengurangi Perilaku Bullying di Sekolah.

Rangkaian kegiatan dalam pengembangan media video bimbingan konseling ini diawali dengan asesmen kebutuhan. Asesmen kebutuhan ini dilakukan untuk mengetahui bagaimana gambaran awal pelaksanaan layanan peminatan di tingkat menengah atas di SMAN 5 Makassar dan khususnya mengenai berbagai kendala yang dialami oleh guru BK terkait layanan informasi untuk mengurangi perilaku bullying siswa di sekolah. Pelaksanaan assesmen kebutuhan dalam penelitian ini dilakukan melalui 2 (dua) cara, yakni dengan melakukan wawancara kepada guru BK dan menyebarkan angket analisis kebutuhan siswa kelas XI untuk mengetahui tingkat perilaku bullying yang terjadi di SMAN 5 makassar.

Berdasarkan hasil asesmen kebutuhan maka dianggap penting untuk melaksanakan pengembangan media video bimbingan konseling untuk mengurangi perilaku bullying di SMAN 5 Makassar. Berdasarkan hal tersebut maka sangatlah penting untuk mendesain dan mengembangkan media video bimbingan konseling. Media aplikasi media video bimbingan konseling ini nantinya diharapkan dapat menjadi alat bantu yang efektif dan efisien bagi guru BK dan siswa untuk mengurangi perilaku bullying siswa di SMAN 5 Makassar.
Terkait dengan analisis kebutuhan yang telah dilakukan maka pengumpulan informasi dilakukan sebelum pengembangan media video baik itu karakteristik siswa, studi literatur mengenai media video bimbingan konseling "Mariki' Berteman" yang kemudian dirumuskan dalam perumusan masalah, dengan kajian literatur dan assesmen kebutuhan untuk mengetahui kebutuhan siswa di sekolah mengenai posisi area implementasi media video. Melalui kajian literatur dan assesmen kebutuhan maka landasan filosofis, psikologis, kerangka teoritis dan implementatif media video ditetapkan. Dengan demikian, diharapkan lahirlah sebuah media video yang berlandaskan pada kerangka teoritis yang kuat dan memiliki peluang implentatif yang baik. Proses semacam ini dipertegas oleh Borg \& Gall dalam Mulyatiningsih (2014) bahwa kajian literatur dilakukan untuk mengumpulkan informasi dalam rangka merencanakan dan mengembangkan media video. Salah satu tujuannya adalah untuk menentukan area kajian atau implentasi media video.

2. Prototipe media video bimbingan konseling untuk mengurangi perilaku bullying di sekolah yang valid dan acceptable

Media video bimbingan konseling yang dikembangkan merupakan suatu layanan bimbingan dan konseling dengan menggunakan media berupa video dan panduan bagi guru bk. Media video bimbingan konseling ini berisi adegan penyebab, akibat dan solusi dari perilaku bullying sedangkan panduan bagi guru bk berisi langkah-langkah pelaksanaan media video bimbingan konseling.

Kelayakan media dan panduan divalidasi oleh ahli, Validasi ahli atau expert judgement bertujuan untuk memperoleh model yang memiliki kegunaan, kelayakan, dan ketepatan yang diperlukan untuk memberikan keyakinan bahwa model tersebut tepat dapat mengubah atau mengembangkan perilaku tertentu sebagaimana yang dimaksud oleh peneliti. Validasi ahli model ini dilakukan melalui pertimbangan atau penilaian ahli (expert judgement) dalam bidang yang berkaitan dengan model ini yakni dalam bidang bimbingan dan konseling, dan ahli media. Berikut tabel hasil analisis validasi ahli: 
Tabel 4.1 Hasil penilaian uji kegunaan (utility) media video bimbingan konseling dan panduannya oleh Ahli 1, 2 dan 3

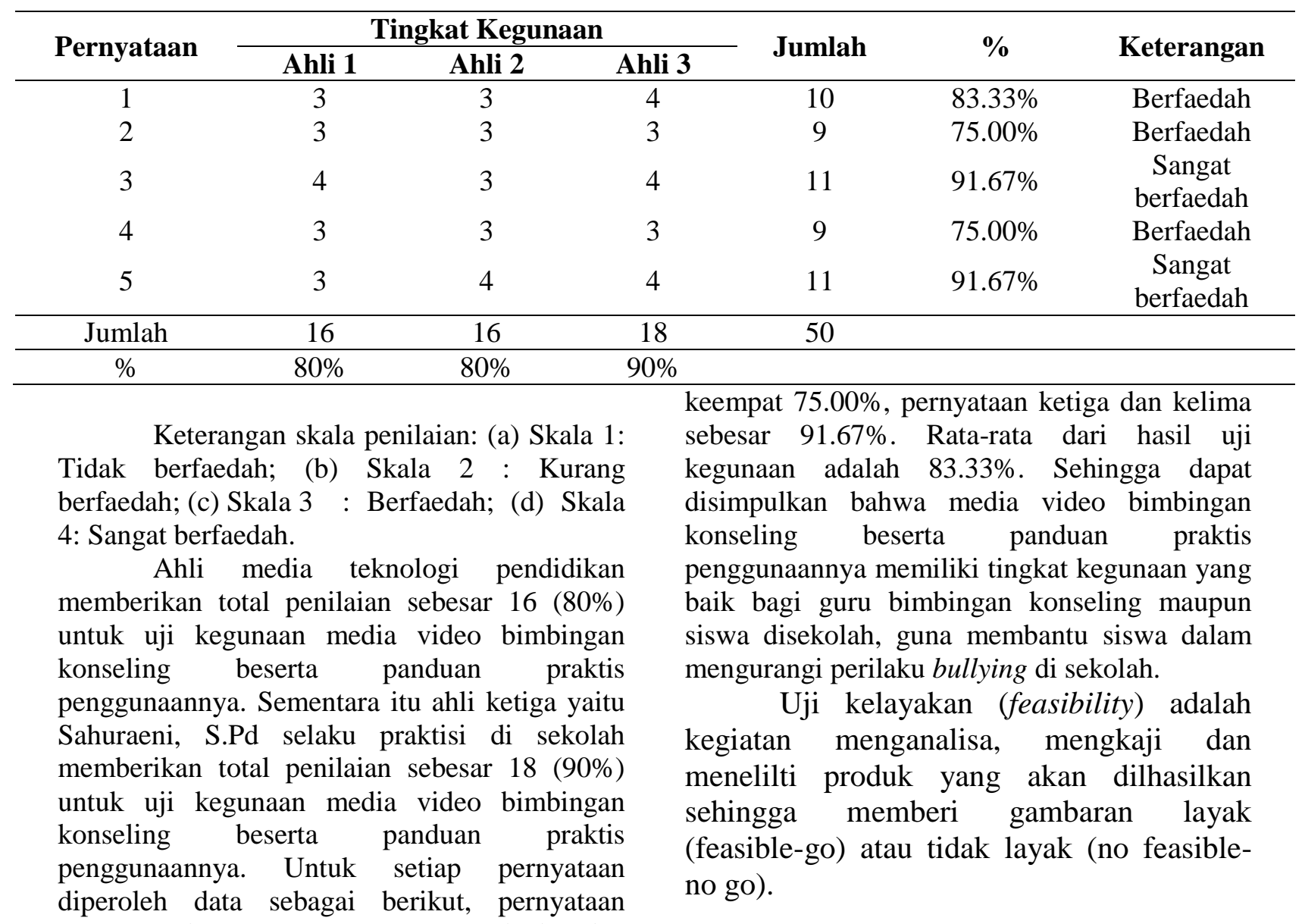
pertama sebesar $83.33 \%$, pernyataan kedua dan

Tabel 4.2 Hasil penilaian Uji kelayakan (feasibility) media video bimbingan konseling dan panduannya oleh Ahli 1, 2 dan 3

\begin{tabular}{|c|c|c|c|c|c|c|}
\hline \multirow{2}{*}{ Pernyataan } & \multicolumn{3}{|c|}{ Tingkat Kelayakan } & \multirow{2}{*}{ Jumlah } & \multirow{2}{*}{$\%$} & \multirow{2}{*}{ Keterangan } \\
\hline & Ahli 1 & Ahli 2 & Ahli 3 & & & \\
\hline 1 & 4 & 4 & 4 & 12 & $100.00 \%$ & $\begin{array}{l}\text { Sangat } \\
\text { lavak }\end{array}$ \\
\hline 2 & 3 & 4 & 3 & 10 & $83.33 \%$ & Layak \\
\hline 3 & 3 & 3 & 4 & 10 & $83.33 \%$ & Layak \\
\hline 4 & 4 & 4 & 4 & 12 & $100.00 \%$ & $\begin{array}{l}\text { Sangat } \\
\text { lavak }\end{array}$ \\
\hline 5 & 3 & 3 & 3 & 9 & $75.00 \%$ & Layak \\
\hline 6 & 4 & 4 & 4 & 12 & $100.00 \%$ & $\begin{array}{l}\text { Sangat } \\
\text { layak }\end{array}$ \\
\hline Jumlah & 21 & 22 & 22 & & & \\
\hline$\%$ & $87.50 \%$ & $91.67 \%$ & $91.67 \%$ & & $90.27 \%$ & \\
\hline
\end{tabular}

Keterangan Skala penilaian

Skala 1 : Sulit dipahami
Skala 2 : Kurang dipahami

Skala 3 : Mudah dipahami 
Skala 4 : Sangat dipahami

Dari hasil uji kelayakan (feasibility) yang dinilai oleh ketiga ahli diatas terdapat 6 item pernyataan akseptabilitas untuk kelayakan media video bimbingan konseling, tiap pernyataan diberikan skala 1-4. Hasil penilaian yang diberikan oleh para ahli adalah sebagian besar penilaian berada pada skala 3 dan 4 . Dijelaskan untuk skala penilaian 3 yaitu memiliki, mudah dipahami, dan jelas. Sedangkan skala penilaian 4 dalam uji kelayakan adalah sangat memiliki, sangat mudah dipahami, sangat besar, dan besar. Adapun pernyataan uji kelayakan media video bimbingan konseling beserta panduan praktis penggunaannya dijelaskan untuk ahli pertama selaku ahli materi psikologi sebesar 21 $(87.50 \%)$, dan ahli kedua selaku ahli media teknologi pendidikan memberikan penilaian sebesar 22 (91.67\%). Selanjutnya ahli ketiga
Sahuraeni, S.Pd selaku praktisi disekolah memberikan penilaian sebesar 22 (91.67\%). Untuk setiap pernyataan diperoleh data sebagai berikut, pernyataan pertama, keempat dan keenam sebesar $100.00 \%$, untuk pernyataan kedua dan ketiga sebesar $83.33 \%$, sementara pernyataan kelima sebesar $75 \%$. Rata-rata dari hasil uji kegunaan adalah $90.27 \%$. Dari hasil skala penilaian yang diberikan oleh para ahli dapat disimpulkan bahwa media video bimbingan konseling beserta panduan praktis penggunaannya ini memiliki tingkat kelayakan (feasibility) yang baik bagi guru bimbingan konseling maupun siswa disekolah, guna membantu siswa dalam mengurangi perilaku bullying di sekolah.

Uji ketepatan (Accuracy) adalah pengujian produk dari aspek kesesuaian perkembangan siswa, kondisi lapangan serta kesesuaian kebutuhan terhadap produk.

Table 4.3 Hasil penilaian Uji Ketepatan (Accuracy) media video bimbingan konseling dan panduannya oleh Ahli 1, 2 dan 3

\begin{tabular}{ccccccc}
\hline \multirow{2}{*}{ Pernyataan } & \multicolumn{3}{c}{ Tingkat Ketepatan } & \multirow{2}{*}{ Jumlah } & $\%$ & \multirow{2}{*}{ keterangan } \\
\cline { 2 - 4 } & Ahli 1 & Ahli 2 & Ahli 3 & & & Sesuai \\
2 & 3 & 3 & 4 & 10 & $83.33 \%$ & Sesuai \\
3 & 3 & 3 & 3 & 9 & $75.00 \%$ & Sangat sesuai \\
4 & 4 & 4 & 3 & 11 & $91.66 \%$ & Sesuai \\
5 & 3 & 3 & 3 & 9 & $75.00 \%$ & Sangat sesuai \\
Jumlah & 4 & 4 & 4 & 12 & $100.00 \%$ & \\
\hline$\%$ & 17 & 17 & 17 & 51 & & \\
\hline
\end{tabular}

Keterangan Skala penilaian

Skala 1 : Tidak sesuai

Skala 2 : Kurang sesuai

Skala 3 : Sesuai

Skala 4 : Sangat sesuai

Penilaian yang selanjutnya adalah uji ketepatan (accuracy). Berdasarkan penilaian yang diberikan oleh ahli terdapat 5 item pernyataan akseptabilitas untuk ketepatan media video bimbingan konseling beserta panduan praktis penggunaannya yang tiap pernyataan diberikan skala 1-4. Hasil penilaian yang diberikan oleh para ahli tidak jauh berbeda dengan hasil penilaian uji kegunaan dan kelayakan media video bimbingan konseling yang sebagian besar penilaian berada pada skala 3 dan 4. Dijelaskan untuk skala penilaian 3 yaitu sesuai, jelas, lengkap dan perlu sedangkan untuk skala 4 dalam uji ketepatan adalah sangat sesuai, sangat jelas, sangat lengkap dan sangat perlu.
Diuraikan ahli pertama selaku ahli materi psikologi memberikan nilai sebesar 17 (85.00\%), selanjutnya ahli dua selaku ahli media teknologi pendidikan memberikan nilai sebesar $17(85.00 \%)$. Sementara ahli ketiga Sahuraeni, S.Pd selaku praktisi disekolah memberikan nilai sebesar $85.00 \%$. Untuk setiap pernyataan diperoleh data sebagai berikut, pernyataan pertama sebesar $83.33 \%$, sementara untuk pernyataan kedua, dan keempat sebesar $75.00 \%$. Kemudian untuk pernyataan ketiga sebesar $91.66 \%$ dan pernyataan kelima sebesar $100.00 \%$. Rata-rata dari hasil uji kegunaan adalah $85.00 \%$. Dari hasil penilaian yang diberikan oleh para ahli dapat disimpulkan bahwa media video bimbingan konseling beserta panduan praktis penggunaannya memiliki tingkat ketetapan (accuracy) yang baik bagi guru bimbingan konseling maupun siswa disekolah, guna membantu siswa dalam mengurangi perilaku bullying di sekolah. 
Berdasarkan validasi isi media video bimbingan konseling, diperoleh hasil yang menunjukkan bahwa semua aspek atau struktur yang membangun media video dan panduan dinilai oleh para ahli psikologi dan desain teknik yang bertindak sebagai validator, telah memiliki kelayakan konseptual yang memadai. Validasi ahli dilakukan dengan melakukan uji validitas media video yang akan dikembangkan kepada tiga ahli untuk menentukan validitas media video yang mencakup kejelasan, kesesuaian, kelayakan, ketepatan pada pemberian media video bimbingan konseling pada siswa SMAN 5 Makassar.

Secara keseluruhan hasil yang diperoleh dari proses validasi yang dilakukan kepada ketiga ahli yakni, validator mengapresiasi media video bimbingan konseling ini mudah untuk dilaksanakan di sekolah-sekolah, sehingga media video sudah layak untuk diujicobakan di lapangan. Akan tetapi media video dan panduan harus tetap dilakukan perbaikna-perbaikan atau revisi sesuai dengan saran yang diberikan guna menyempurkan media video bimbingan konseling dan panduannya. Hal ini dilihat dan disimpulkan berdasarkan hasil skala validasi yang dinilai oleh ketiga ahli. Hasil uji validitas yang telah dilakukan dijadikan sebagai bahan revisi media video dan panduannya sebelum diujikan ke lapangan secara langsung.

\section{Keberterimaan media video bimbingan konseling untuk mengurangi perilaku bullying di sekolah}

Proses uji coba kelompok kecil dilakukan untuk mengetahui gambaran media video bimbingan konseling untuk mengurangi perilaku bullying siswa di SMA yang telah terkembangkan. Adapun dari pemberian skala bullying siswa sebelum dan sesudah pemberian media video bimbingan konseling diperoleh hasil yakni ada perubahan sikap yang cukup signifikan setelah pemberian media video bimbingan konseling. Hal ini berarti kegiatan layanan dengan menggunakan media video bimbingan konseling dapat digunakan untuk mengurangi perilaku bullying siswa.

Untuk melihat keberterimaan dan respon siswa terhadap kegiatan pemberian layanan dengan media video bimbingan konseling yang digunakan, maka peneliti kemudian juga memberikan lembar respon yang kemudian didapatkan hasil bahwa siswa memberikan respon yang positif (baik sekali) atas adanya layanan dengan media video bimbingan konseling ini.
Beberapa komentar dan saran yang diberikan siswa bahwa kegiatan dalam pemberian media video bimbingan konseling ini merupakan hal yang baru dirasakan oleh siswa, mudah dan menyenangkan dan sangat membantu siswa dalam memahami bahaya bullying, serta menumbuhkan rasa peduli dan empati siswa. Para siswa menyarankan agar kegiatan seperti ini bisa terus dilaksanakan dengan berbagai penyempurnaan pengembangan terkait media video yang diberikan.

Tingkat perilaku bullying di SMAN 5 Makassar sebelum penayangan media video bimbingan konseling yang diberikan kepada 10 siswa, jawaban ya berada dalam kategori tinggi dengan presentase $(81 \%)$, kemudian jawaban tidak, kategori rendah dengan presentase (19\%). Namun setelah diberikan penayangan media video bimbingan konseling tersebut, maka tingkat perilaku bullying pada siswa menunjukkan adanya perubahan, jawaban ya berada dalam kategori rendah dengan presentase (28\%), kemudian jawaban tidak kategori tinggi dengan presentase $(73 \%)$. Hal ini menunjukkan adanya perubahan tingkat perilaku bullying sebelum dan setelah penayangan media video bimbingan konseling. Hal ini berarti media video bimbingan konseling dapat mengurangi perilaku bullying di SMAN 5 Makassar.Media Video menunjukkan dapat menjadi layanan dalam mengurangi prilaku terkait bullying,

\section{SIMPULAN DAN SARAN}

Merujuk pada tujuan dan tahap pengembangan, serta hasil dan pembahasan penelitian, maka dapat ditarik beberapa kesimpulan: (1) Gambaran kebutuhan media video bimbingan konseling untuk mengurangi perilaku bullying di SMAN 5 Makassar menunjukkan bahwa media video sangat penting dan dibutuhkan; (2) Prototipe media video bimbingan konseling yang dikembangkan telah valid dan acceptable untuk mengurangi perilaku bullying di SMAN 5 Makassar; (3) Keberterimaan media video bimbingan konseling yang diberikan kepada 10 siswa dalam uji kelompok kecil menunjukkan adanya perubahan tingkat perilaku bullying sebelum dan setelah penayangan media video bimbingan konseling. Hal ini berarti media video bimbingan konseling dapat mengurangi perilaku bullying di SMAN 5 Makassar.

Berdasarkan hasil penelitian yang telah dilakukan dan dinyatakan layak untuk 
digunakan dan memberikan implikasi kepada berbagai pihak sehingga direkomendasikan terhadap pengembangan ilmu pengetahuan, pemecahan masalah pendidikan, pengembangan kelembagaan dan penelitian lebih lanjut. (a) Pengembangan ilmu pengetahuan, hasil penelitian ini menunjukkan bahwa media video bimbingan konseling, baik dari segi konseptual maupun dari segi praktis memiliki kelayakan untuk diimplementasikan di sekolah. Dari segi pengembangan ilmu, media video bimbingan konseling ini dapat memberikan kontribusi bagi pengembangan ilmu bimbingan dan konseling; (b) Pemecahan masalah pendidikan, media video bimbingan konseling ini didasarkan atas kebutuhan akan adanya suatu media yang dapat digunakan oleh guru BK dalam membantu mengatasi permasalahan siswa di sekolah, terutama bagi siswa yang menjadi pelaku dan korban bullying. Berdasarkan pertimbangan kebutuhan dan masalah tentang bimbingan konseling tersebut maka hasil penelitian ini direkomendasikan untuk dilaksanakan di sekolah agar dapat membantu guru BK dalam mengurangi perilaku bullying siswa di sekolah; (3) Diharapkan bagi peneliti lain untuk dapat melanjutkan penelitian pengembangan media video bimbingan konseling agar media video dan panduannya dapat digunakan di sekolah. Bagi peneliti yang bermaksud mengembangkan penelitian ini dapat melakukan pengujian terhadap subyek dengan latar belakang dan karakteristik yang berbeda termasuk dalam jumlah subyek yang lebih besar.

\section{DAFTAR RUJUKAN}

Aryani, F., \& Bakhtiar, M. I. (2018). Effect of assertive training on cyber bullying behavior for students. Konselor, 7(2), 78-88.

https://doi.org/10.24036/0201872102830-00

Bakhtiar, M. I. (2015). Pengembangan Video Ice Breaking Sebagai Media Bimbingan Konseling dalam meningkatkan keterampilan sosial siswa. Jurnal Psikologi Pendidikan dan Konseling, 150-162.

Batubara, H. H., \& Ariyani, D. N. (2016). Pemanfaatan Video sebagai Media
Pembelajaran Matematika SD/MI.

MUALLIMUNA: Jurnal Madrasah

Ibtidaiyah, 2(1), 47-66.

Costrie G.W. (2009). Fenomena Bullying di Sekolah Dasar Negeri di Semarang. Jurnal Psikologi. 5(2), 4-10

Developed for the Department for Children, S. and F. (DCSF). (2007). Cyberbullying. Sherwood Park Annesley: DCSF Publications Sherwood Park Annesley Nottingham NG15 0DJ. Retrieved from www.teachernet.gov.uk/publications.

Komisi Nasional Perlindungan Anak. (2014). Database Pelanggaran Hak Anak Tahun 2010. Jakarta: Komisi Nasional Perlindungan Anak.

Mulyataningsih, E. 2013. Metode Penelitian Terapan Bidang Pendidikan. Anggota Ikatan Penerbit Indonesia (IKAPI): Alfabeta

Modecki, K. L. (2014). Bullying Prevalence Across Contexts: A Meta-analysis Measuring. Journal of Adolescent Health, 55(5), 602-611.

Kowalski, R. M. (2013). Psychological, Physical, and Academic Correlates of Cyberbullying. Journal of Adolescent Health, 53(1), 13 - 20.

Pribadi, Benny Agus. (2004). Materi pokok Media Teknologi. Jakarta: Universitas Terbuka.

Salmivalli, C., Lagerspetz, K., Björkqvist, K., Osterman, K., \& Kauki-ainen, A. 1996. Bullying as a group process: Participant roles and their relations to social status within the group. Aggressive Behavior, 22, 1-15.

Tani, F., Greenman, P.S., \& Schneider, B.H., et al. 2003. Bullying and the Big Five: A study of childhood personality and participant roles in bullying incidents (abstrak). School Psychology International. (24)2,131-146. 
Wang, J. L. (2009). School Bullying Among Adolescents in the United States: Physical, Verbal, Relational, and Cyber. Journal of Adolescent Health, 368 375. 